\title{
Beyond dogmatism: Rationality in theology and science
}

\author{
Wentzel van Huyssteen \\ University of Port Elizabeth
}

\begin{abstract}
Beyond dogmatism: Rationality in theology and science

The justification of cognitive claims in theology can be dealt with adequately only if the epistemological issues of metaphorical reference, experiential adequacy and explanatory progress are seen as crucial problems for the more encompassing problem of rationality in theology. To claim some form of reality depiction the theologian will have to argue for a plausible theory of reference on the basis of interpreted religious experience. In this discussion important analogies between the rationality of theological theorizing and the rationality of science are revealed. Thus explanatory progress in theology shows itself to be a form of inference to the best explanation, and the rationality of both theology and science is therefore determined by certain epistemic values.
\end{abstract}

Critical theologians, in an attempt to transcend the intellectual coma of fideism and dogmatism, have to face up to a very special kind of challenge: the truth claims of religious assertions. Religious beliefs are normally held to be true, not merely useful, and their assertions about reality are universal in intent. This also raises the question of the possible role of explanatory justificasion in theology: what do religious beliefs explain and can their cognitive claims be justified in any way?

The theologian of course has to realize that the questions raised by reflecting on religion are not those raised by science. Accepting that different kinds of knowledge are involved in the practices of science and theology and that neither can provide the content of the other's knowledge, does not mean that they do not inform the context within which their respective knowledge is to be constructed (cf Barker 1981:

\footnotetext{
* This paper was presented at the Second European Conference on Religion and Science, University of Twente, Enschede, The Netherlands, March 10-13, 1988. An earlier version of this paper was recently read at the Theology and Science Consultation of the Annual Meeting, American Academy of Religion, Boston, USA, December 7, 1987.
} 
276). This epistemological problem reveals the common adherence of theology and all the sciences to the problem of rationality, as we shall soon see. It also challenges us to evaluate the role of justification and explanation in both theology and science.

The relationship between explanatory power and truth has always been a central issue in the understanding of science, and is today even more problematical (McMullin 1986: 52). Philosophers of science have also convincingly pointed out that there can be no undisputed and monolithic notions of 'reality' or of 'explanation' in science: the objects of our interest not only dictate different strategies, but also different views on what could be regarded as adequate forms of explanation. But the central question remains: does theology exhibit a rationality comparable to the rationality of science, and how plausible can an explanatory justification of the cognitive claims of theology be?

In this paper I would like to show that the rationality of science and theology is in each case determined by certain goals and criteria, that is, by certain epistemic values. In both theology and science, whatever their other differences might be, the supreme value that determines rationality is intelligibility. What is real for theology and for science is not the observable but the intelligible (cf Barbour 1971: 170), and in both theology and science beliefs and practices are attempts to understand at the deepest level, where understanding can be construed as seeking the best explanation (cf Proudfoot 1985: 43). What is at stake, therefore, is not only the general epistemic status of religious belief, but especially the implications this will have for the epistemic and thus rational integrity of theological discourse as such. At the same time the high degree of personal involvement, that is of faith and commitment, in religion and theology will present a very special challenge to any theory of rationality in theology. Because of this, and because of the contextuality of religious experience and the cognitive claims that arise from this, I shall argue for a theory of rationality in theology that encompasses both experiential adequacy and epistemological adequacy.

\section{RATIONALITY IN THEOLOGY AND SCIENCE}

Constructing a model of rationality that can deal adequately with a theology that claims cognitivity and reality depiction for its central statements, will certainly not be an easy task. Not only is rationality a 
word protean in its meanings (cf Echeverria 1986: 372), but the lasting influence of positivism and the prestige of the natural sciences is a direct challenge, not only to our view of the sciences (cf Schoen 1985: vii), but also to our concept of rationality. Post-Kuhnian philosophy of science has shown us that there can be no sharp line of demarcation between scientific rationality and all other forms of rationality (cf Van Huyssteen 1986: 63ff). In fact, rationality in science relates to the 'reasonableness' or a more basic kind of rationality that informs all goal-directed human action. In this sense one might have a richer theory of rationality that not only includes emperical adequacy but also compatability with metaphysical or philosophical theories (cf NewtonSmith 1981: 7).

In spite of some important differences between theology and the other sciences, I would identify rationality as an epistemological issue that ties in directly with the overall goals of theology and science, that is, intelligibility as an understanding at the deepest possible level. In this sense rationality would imply a reliance on argument and explanation and in accepting those models which appears to be the most effective problem solvers in terms of certain criteria of rationality. These criteria could be seen as rules specifying what would count as reasons for believing something. In this sense they function as epistemic values that directly tie in with the goals of our theorizing. Rationality in theology and science is therefore directly related to these goals, and if the goals change or more important ways of realizing these goals are found, rationality itself will change (cf McMullin 1987: 17). And if science and theology are complex intellectuals activities of specific communities of inquirers, there is no way to prescribe a certain 'type' of rationality for that activity without looking at its actual practice.

With this in mind, it is important to reflect on the fact that Ian Barbour (cf Barbour 1971) has already identified a critical realist model of rationality that accommodates the inter-action of experience and interpretation, the use of models and analogies, and the role of a community of inquiry in both theology and science. Barbour's argument that personal involvement in science and religion differ only in degree and that the knowing subject always makes an important contribution to all knowledge, will not only have to be developed further but will also have profound implications for the problem of rationality in theology.

In theology we seek as secure a knowledge as we can achieve, a knowledge that will allow us to understand and where possible to 
construct theories as better explanations. This goal of theology not only determines the rationality of theology, but very much depends on the way we deal with the problem of the justification of cognitive claims in theology. And if in both theology and science we want to understand and explain, then surely the rationality of science is directly relevant to that of theology.

\section{CRITICAL REALISM IN THEOLOGY}

In any analysis of the development of theories of rationality in contemporary philosophy of science, the very recent development of different forms of qualified scientific realism after decades of positivism and the ensuing constant threat of a post-Kuhnian paradigmatic relativism, can definitely be seen as one of the most remarkable and welcome features of the scientific thought of our time (cf Burham 1985: 28). The fact that the concept 'realism' can in an epistemological sense be called the catch-word of the 1980's (cf Peacocke 1984: 11) and that there seem to be almost as many scientific realisms as there are scientific realists, was discussed at length in my Theology and the Justification of Faith (1986) and The Realism of the Text (1987). What is of importance for this paper is that in scientific realism the notion of explanatory success is central as is the view that there is good reason to believe in the existence of entities substantially like those postulated by theories that have been successful over a long period of time.

Ernan McMullin (1986: 57) who opts for this kind of restricted realism, also qualifies this definition in some important ways:

- realism commits one to saying that there are 'good reasons' but not that there are compelling grounds. The logical possibility that even a highly successful theory might be false, should be held open;

- any theory may therefore develop further and can in principle be revised and sharpened;

- only theories that have already shown a considerable degree of explanatory power would qualify as having reliable ontological implications;

- the explanatory success of a theory suggests truth and never implies truth.

The success of a theory in a qualified form of scientific realism does therefore not warrant the claim that something exactly corresponding to 
this construct exists. The success of a theory can at best warrant a claim that an entity possessing among others the properties attributed to it by the theory, exists. This not only accounts for the notion of approximate truth in realism, but also for the central role of metaphors in scientific theorizing (cf McMullin 1984: 30ff). Theories - and their metaphors thus provide epistemic access to entities that could not have been known otherwise.

For the theologian realism as an epistemological theory of rationality, is of course very appealing because it is rather obvious that Christians have traditionally been realists one way or the other (cf Soskice 1987: 109). The problem is, however, if this position can be philosophically defended, and if so, what form of realism would be appropriate for theology? And even more important: what specific problem should realism in theology address? I will eventually argue for a qualified and weak form of critical realism in theology: a realism that does not offer a strong defence of theism but deals with the cognitive claims of religious language and theological reflection. And to counter the claims of the instrumentalist that religious language provides a useful system of symbols which can be action guiding and meaningful for the believer without being ontologically referential or reality dipicting, the critical realist in theology will have to attempt to say how religious language can claim to be about God at all.

I therefore am convinced that anyone considering the possibilities of qualified forms of realism for theology should be extremely wary of an uncritical, superficial transferring of the realism of science to the domain of religious belief, and to theology as the reflection on the claims of this belief. At the basis of the reasons for using this term is the conviction that what we are provisionally conceptualizing in theology, really exists. This basic assumption and the good reasons we have for it, makes it possible for theologians, like scientists, to believe they are theorizing in a valid, progressive and therefore successful way.

The strength of the critical realist position certainly lies in its insistence that both the objects of science and the objects of religious belief lie beyond the range of literal description (cf McMullin 1985: 47). I personally think this eventually represents a major advance in our understanding of what not only science, but also theology, can achieve. To put it in Arthur Peacocke's (1984: 51) words: the scientific and theological enterprises share alike the tools of groping humanity: words, ideas, images that have been handed down, which we refashion in our own way for our own times in the light of present-day 
experience. Science and theology, for the Christian, can therefore only be seen as interacting and mutually illuminating approaches to reality. What exactly is meant by 'reality' in this context, will of course have to be carefully analysed. I think Peacocke, as regards the issue of reality in science and theology, is correct in warning against a form of discrimination when we attribute 'reality' as such. Indeed there is no sense in which subatomic particles are to be regarded as 'more real' than a bacterial cell or a human person or, even, social facts or God (Peacocke 1984: 36).

When Peacocke, however, proceeds to relate these realities to different levels of reality, a cut through the totality of reality, it does become more problematical. It could imply that realism should then apply in a similar way to the fields of both science and theology, which would be highly problematical. I think McMullin (1985: 39) pinpoints the problem by underlining the fact that there is no way that science and theology could deal with the same reality, and rather than saying that there are different 'levels' of reality, one should realize that science and theology for the most part deal with different domains of the same reality. He states it very clearly (McMullin 1985: 40): 'Science has no access to God in its explanations; theology has nothing to say about the specifics of the natural world'.

Where I do, however, think the two overlap, is on the epistemological level of reflection or human knowledge: each has something important to say about two very different but also very important domains of reality. To me this is crucial: it is on this level, the problem of the reliability of theological knowledge and the justification of its cognitive claims, that a theory of critical realism will have to be put to the test and not at all in the sense of 'proving' that the Reality theology is talking about, really exists or could be only a 'useful fiction' for helping people to lead better lives. In this sense McMullin (1985: 39) also sympathizes with the claim that both science and theology could be regarded as 'realist', that is, as making reliable truth-claims about domains of reality that lie beyond our experience.

\section{RATIONALITY AND REFERENCE}

The problem of the justification of the cognitive claims of theological statements has now been rephrased as the question of how religious and theological statements can claim to be about God at all. This 
question has not only surfaced as the central problem for any qualified form of critical realism in theology but also implies further problems such as: how do we know that religious and theological language manage to refer and can be regarded as reality-depicting? How is reference fixed in religious and theological language, and is it fixed in such a way that the cognitive claims of theology can be justified one way or the other? The answer to these questions will prove to be directly related to the way metaphor function in religious language. It will also determine the epistemological adequacy of critical realism as a model of rationality for theology, and because of the experiential grounding of metaphorical concepts (cf Botha 1986: 380; Lakoff and Johnson 1980: 19f), will provide a key to experiential adequacy in theological theorizing.

The high degree of personal involvement in theological theorizing not only reveals the relational character of our being-in-the-world, but epistemologically implies the mediated and interpretative character of all religious experience. In a sense one's concept of experience will therefore entail one's concept of meaning, which in turn will determine one's concept of knowledge (cf Gill 1981: 19). On this view, religious experience and the way we define it, serves as a matrix out of which meaning and knowledge as a basis for theological theorizing arises. But religious language is the way in which alleged religious experiences are expressed, and in this sense no religious experience can be seen as pre-linguistic or uninterpreted. The theory-ladeness of all data in the sciences thus parallels the interpreted nature of all religious experience. The underdetermination of theories by data is therefore - epistemologically - as important in theology as in the sciences (cf Van Huyssteen 1987: 32ff).

The important fact that all religious experience is interpreted experience therefore implies that religious language is constitutive of experience as much as it is expressive of it. And because of the mediated structure of the religious dimension of all experience, other experiences provide the context for religious awareness. But even more important: if religious experience is mediated and intentional, then the most appropriate language form for this type of experience would be metaphorical language. In fact: the use of metaphors and models in religious cognition - a use which parallels that in scientific cognition - also argues for the claim that the structure of religious cognition is that of interpreted experience (cf Rottschaefer 1985: 269).

The basic question now emerging from all this is: how is the alleged 
cognitive claims or referential value of religious language - and eventually also of theological language - affected if all religious experience is interpreted experience and thus articulated in theory-laden terms emerging from a particular tradition of faith? This question can also be phrased in a different way: how can metaphorical language be referential and reality depicting prior to and without definite knowledge of the referent? (cf Soskice 1987: 111). In other words, how can we know that religious language, and the theological theories that are creatively constructed in terms of this language, refer if that to which it refers is still unknown to us?

Regarding this important problem and its direct relevance for the problem of the justification of the cognitive claims of theological statements, important studies by Saul Kripke (1972) and Hilary Putnam (1975) argue that reference can indeed take place independent of the possession or availability of any definite description or definite prior understanding of what is being referred to. The reason for the referential character of religious metaphorical language will therefore not so much be any prior or 'given' knowledge of what is being referred to, but the fact that a speaker is a member of a linguistic community who has passed on the information, going back to the person or event itself (cf Kripke 1972: 295). The notion of reference here is obviously an epistemic one. And the issue at stake concerning this reference is the role of a concept or metaphor in making possible socially coordinated epistemic access to whatever is being referred to (cf Boyd 1980: 358).

On this view reference therefore depends on a chain of historical and contextual communication, and this chain of communication is there by virtue of the membership of a community which passes on a name, or the meaning of an event from link to link. What is impotant is not first of all how the speaker got the reference, but the actual chain of communication (cf Kripke 1972: 300). This obviously does not mean that every sort of causal chain reaching us will warrant reference: we refer to someone or something by virtue of our connection with other speakers in a community, going back to the referent itself. In some way the referent must be historically, or we might even say causally connected to the speech act (cf Donnellan 1972: 377).

From this we can conclude that if reference or reality-depiction in theology depends on both context and content and can be regarded as a statement dependent motion (cf Soskice 1987: 112), then theological statements derive from interpreted religious experience. In this sense the context as well as the content - which have been 'passed on' in 
tradition and is now being refered to - determine the meaning and cognitive claim of what is being referred to. It now not only becomes possible, through the provisional constructs of theological theories, to fix reference prior to and apart from any definitive knowledge, but in a critical realist interpretation of theory terms it is the metaphorical concepts that provide an epistemic access to that which is being referred to.

The function of metaphor and model in religious and theological language thus becomes crucial for a weak form of critical realism that is not set on presenting a strong defence of theism, but rather a justification of the cognitive claims of theological reflection: why theological statements can claim to be about God at all. Theological theories, and their flexible and open-ended networks of metaphorical concepts, while not necessarily directly or exhaustively descriptive in a positivist or naive realist way, can nevertheless claim to be referential or realitydepicting. This not only justifies the use of metaphor in theory construction in theology and science, but also strengthens the case for a qualified form of critical realism in theology.

All language, but especially metaphorical language, is therefore contextual language embedded in certain traditions of conviction, reflection and investigation which in its turn determine the interpretative character of experience. This is also true of theological language which basically reflects on religious experience and the ensuing religious language as ways to the Reality that Christians believe is God. But these experiences and their accompanying metaphorical language, can only be reliably interpreted in terms of the hermeneutical tradition of a linguistic community who has passed on the root metaphors of the Christian faith through a long historical and interpretative tradition going back to the classical texts of this tradition of faith. In this sense - and not in any fundamentalistic sense - the referential nature of the central metaphors of the Bible fixes the referent and in itself becomes a reality that functions epistemologically and hermeneutically as a very exclusive access to the Reality that is God. In this sense this classic text is the ultimate 'way' to the reality claimed by theology, an epistemological claim that might be defined as the realism of the text (cf Van Huyssteen 1987: 30).

In a very important way reference or reality-depiction as well as critical realism in theology is therefore supported by:

- the fact that the Bible, as classic text of the Christian faith has 
survived as a religious text and as a book of faith in a long and remarkable interpretative tradition of an ongoing faith context;

- the reality of ongoing faith experiences that this text has evoked through centuries of belief in God, and the way in which the same text today still appeals to Christian experience. Of these experience, of which God is believed to be the cause, theological theorizing provides interpretation and reinterpretation on the basis of the central metaphors of this text. This allows us to refer to God without describing him in terms of any definite prior knowledge or understanding;

- the metaphorical structure of biblical language and the continuity of reference this has creatively given to religious and theological language through the ages. This obviously presupposes a languageusing community (cf Peacocke 1984: 47) going back to the initiating events when these metaphorical terms were first introduced and the referent fixed.

Reference in theology is therefore not determined by any prior knowledge of the referent but by the history of religious experience as contextual and relational, interpreted and mediated experience. Reference or reality depiction thus directly relates to the fact that the speaker is a member of a community of speakers who - through a tradition of historical links - speak in a certain way, a way that implies certain 'baptismal events' as well as a corresponding commitment to an ultimate commitment, that is, to finding maximal meaning in life. After all, it is not words which refer but speakers using words who refer (cf Soskice 1985: 136).

A critical realist argument in theology thus becomes possible if we dispense with the empiricist dogma that reference is fixed only by unrevisable description or not at all (cf Soskice 1985: 151). What is more: the case for critical realism in theology can therefore never be argued only in terms of some form of explanatory success analoguous to that of the natural sciences, but in an important way becomes plausible in terms of metaphorical reference. And what is offered is no strong form of defense of theism but an attempt to argue how and why religious language and the theories of theology can claim to be about God at all. This also answers the question whether and to what extent an individual's religious experience could provide a proper basis or a justification of religious belief (cf Runzo \& Ihara 1986: xi).

The difference between realism in science and critical realism in 
theology is obviously directly related to the difference in degree of a personal involvement in theology and science respectively. Not only can religious experiences not be repeated under controlled circumstances, but using them to fix reference involves commitment to the validity of the experience as reported by the experiencer (cf Soskice 1987: 115). Theology, in its attempt to obtain maximum intelligibility, thus makes claims based on religious experience. And as in science, although different from the kind on which scientific statements are based, this experience is understood as a context of shared assumption interpreted within the wider framework of a continuity of metaphorical reference. In both religion and science claims are made within a context of enquiry, but this does not deprive them of their referential value and therefore is not a relativist position. Those metaphoric and interpreted expressions around which the language of the Christian religion cluster, can in this sense be said to have justified themselves as meaningful and referential to vast numbers of people throughout the centuries and across cultures. It is this kind of experiential adequacy, and not a justified certainty, which makes a belief a responsible belief. And a model of rationality which can accommodate this, is already justifying its claim to epistemological adequacy.

\section{EXPERIENCE AND EXPLANATION}

The justification of cognitive claims in theology through the grounding of reference in religious experience is supported by the fact that scientists and philosophers of science have not as easily as literary critics and some theologians, turned to non-cognitivist views of metaphor. The most interesting metaphors in both theology and science are those which suggest an explanatory network and are vital at the 'growing edges' of our reflection (cf Soskice 1985: 101f). The crucial issue of course is: what do theological theories explain, and will a form of explanatory justification in theology have implications for the cognitive claims of theological theories? I would like to argue that although there might be no epistemological short cut possible from the exlanatory success in science to progress and problem-solving in theological theorizing, this explanatory progress elucidates religious experience and theological reflection in such a way that theology can indeed claim a form of truth approximation.

The belief that religious statements, and per implication also theo- 
logical theories, can never be seen as truly explanatory, remains an extraordinarily pervasive one (cf Schoen 1985: 24). Misconceptions as to the nature of science usually underlies those arguments that would want to object to any analogies between religious and scientific belief. The way contemporary philosophers of science deal with the problem of rationality in scientific reflection, has however done much to challenge this widely held prejudice. Over against Thomas S Kuhn's unability to account for the resolution of theoretical disagreements, and for the success of science, realism claims that many of the current theories of science are probably approximately true and that this assumption provides the best explanation for the success of science. The realist argument therefore in a very important way reveals the importance of inference to the best explanation for science (cf Banner 1986: ii).

The type of critical realism that I would like to develop as a model of rationality for theology, would maintain that the same style of argument - in conjunction with metaphorical reference and epistemic access to the referent of theological theorizing - has a significant role to play in the justification of the cognitive claims of theology. This again, in spite of the admittedly different tasks of realism in theology and science, implies a strong analogy between religious and scientific belief. The notion that religious belief and the cognitive claims of theological reflection can be given some sort of explanatory justification rests on the supposition that these beliefs indeed function as explanations in theological argument. And if this is indeed so, Anthony O'Hear's conviction that the interpretation of religious experience is quite deficient in explanatory power (cf O'Hear 1984: 44ff), will not qualify as a 'better explanation' for the nature of theological theorizing.

Because of the referential nature and resulting reality depiction of theological statements, not only religious beliefs and practices, but also and especially theological theorizing are attempts to understand, where understanding can be construed as seeking the best explanation (cf Proudfoot 1985: 43). Of course there are important differences between the interpretation of religious experiences, the hermeneutical interpretation of religious texts and methods of explanation in the mature sciences. But the interpretation of experience or texts does not preclude the further step of seeking the best explanation for a belief. In fact, finding better and more valid interpretations for experiential or conceptual problems in theology (cf Van Huyssteen 1986: 206f), will imply an inference to the best explanation in theological theorizing. The 
approximate but tentative truth claim implied by this is what a weak form of critical realism is all about.

Representatives of the hermeneutical tradition and those of the natural sciences often see this interpretative tradition and inferential procedures as mutually exclusive. In theology, however, both these tasks, although different, are required to reach maximal intelligibility as the overall goal of theological theorizing. In fact, all contextual, experiential and hermeneutical issues in theological theorizing presupposes an epistemological model of rationality. And the rationality of a critical realist theology is directly determined by the goals, that is, by the epistemic values of theological theorizing. As epistemic values or criteria for theology I would suggest:

- the reality depiction of theological statements, both in an ontological and contextual sense;

- the ability to critically identify and solve problems, in this case experiential and conceptual problems;

- the constructive and progressive nature of theological theorizing.

In the construction of theories in theology it thus becomes possible, in terms of epistemological and experiential adequacy, to identify, eliminate or at least reduce experiential and conceptual problems. And although no strong claim for convergent truth can be shown to be plausible for theological theorizing, the arguments for explanatory progress and metaphorical reference does make it possible to claim truth approximation. In critical realism the only means open to us for judging the provisional or approximate truth of a theory is therefore through as assessment of its explanatory progress.

Explanatory progress in theology thus shows itself to be a form of inference to the best explanation: the approximate truth or likelihood of a theory depends on the degree of explanatory progress the theory enjoys. In theology a 'better' explanation or hypothesis is one that solves experiential problems as well as reduces conceptual problems arising from interpreted, mediated religious experience. This leads one to infer that such a theory is 'true' in the sense of highly likely, and can therefore claim approximate truth. To infer in this sense, is strictly speaking, to conjecture, and where inference comes in is in concluding that a specific theory is in fact the best available explanation. Ernan McMullin (1986: 65) formulates it like this: 'we do not infer to the best explanation; we infer that a given explanation is the best available explanation'. 
In this sense, also in theology, we do not infer to the best explanation, but from the claim that a given theory is the best explanation to the conclusion that this explanatory hypothesis is highly likely.

Inference from the best explanation, or rather from explanatory progress, commits the critical realist in theology to saying that there are good argumentative reasons for holding on to a theory, but not that there are compelling grounds. The logical possibility that even a highly progressive theory might be false, should thus in principle be held open. Any theory in theology may therefore be developed further and can in principle be revised and sharpened. The problem-solving and progressive nature of a theory in theological theorizing can therefore provisionally suggest truth approximation, but can never claim truth in a direct sense. In terms of the overall goal of intelligibility in theology, rationality in theology implies the acecptance of those models which are the most effective problem solvers.

Because of the metaphorical roots of these models and the epistemic notion of reference they imply, explanatory models in theology should indeed be taken seriously but not literally. The metaphors of our explanatory models and theories indeed refer, but because we have no (and need no) prior knowledge of that which is being referred to, this metaphorical reference and the resulting explanatory progress in theory constrution, can never be literal. They do, however, provide exciting epistemic access in the difficult process of theorizing in theology. The cognitive function of models in theological theorizing is therefore primary and forms the basis for all affective, hermeneutical and contextual claims in theology.

In theology, as in science, models are used as explanatory, and in both models are indispensable. And although the basis from which a model may claim to depict reality differs between religious and scientific ones, their application as explanatory is not as different as is so often suggested (cf Soskice 1985: 112).

\section{RATIONALITY AND COMMITMENT}

The central role of experience and explanation in the justification of the cognitive claims of theology, finally implies that the very important distinction between commitments, an ultimate commitment, beliefs and religious faith should always be maintained. I am also convinced that no strong form of justification is possible for a commitment to an 
ultimate commitment (ie, the search for maximal meaning in life), outside the way of life of which it forms part. This is no retreat to irrationalism, because experiential and epistemological adequacy - and not justified certainty - makes a commitment and its resulting beliefs and propositions valid and responsible. This also implies that the beliefs that are implied in a commitment (whether to realism, to the Christian faith or to critical realism in theology) should in principle always be open to criticism. This does not go against what, from a perspective of religious experience, could be called the certainty of faith. It does, however, imply a highly critical sensitivity towards the construction of theories in theology and certainly prevents any form of dogmatism in theological theorizing.

In a critical realist model the beliefs implied in a commitment to an ultimate commitment could never be justified by any foundationalist doctrine of justification, but it might indeed be possible to provide good or adequate reasons for not giving up a commitment and its implied propositional beliefs. Beliefs are therefore never just the 'frills on a commitment' (cf Trigg 1977: 36), but can in a process of explanatory progress offer good reasons why it would make more sense (ie be more rational) to be committed to a certain way of life than not to be committed to it. In this sense there is no contrast between scientific and religious beliefs, nor between a commitment to realism in science or a commitment to critical realism in theology.

We could therefore say that all commitments must involve beliefs (are propositional) which might eventually turn out to be true or false. On this view - which is also my own - it is therefore not enough to maintain that beliefs have a 'truth' which is relative only to a group, a society or a conceptual system. Obviously a conceptual framework or paradigm could involve beliefs which are only true within this context, but eventually we are of course confronted with the meaningfulness or provisional truth of the paradigm as such, as well as being committed to a certain set of beliefs. Such a commitment should be based on beliefs which are themselves external to the system. This is what I tried to indicate throughout as epistemological adequacy: Beliefs that function as criteria for rationality or epistemic values in a critical realist approach to theorizing in theology.

Basic to all this is the conviction that there is an undeniable religious dimension to human existance and that this dimension would be unintelligible without reference to God or a transcendent being. Religious experience and theological explanations thus open up the way for 
a tentative, provisional justification of the cognitive claims of theology, and for the claim of theological statements to be about God at all. This weak form of critical realism therefore argues for the credibility of a commitment to the Christian faith. In this sense theology and its explanations might differ from the other sciences, but it certainly is no less rational.

\section{Work cited}

BANNER, MC 1986. The justification of science and the rationality of religious belief. Unpublished D Phil thesis, Oxford University.

BARBOUR, IG 1971. Issues in science and religion. New York: Harper \& Row.

BARKER, E 1981. Science as theology: The theological functioning of Western science, in The sciences and theology in the twentieth century. Notre Dame: University of Notre Dame Press.

BOTHA, E 1986. Metaphorical models and scientific realism. Proceedings of the Philosophy of Science Association 1, 374-383.

BOYD, R 1980. Mataphor and theory change: What is a 'metaphor' for?, in Ortony, A (ed), Metaphor and thought, 357-390. Cambridge: Cambridge University Press.

BURHAM, FB 1985. Response to Arthur Peacocke. Religion and Intellectual Life 2, 27-31.

DAVIDSON, D \& HARMAN, G (ed) 1972. Semantics of natural language. Dordrecht: Reidl.

DONNELLAN, KS 1972. Proper names and identifying descriptions, in Davidson \& Harman 1972: 356-378.

ECHEVERRIA, EJ 1986. Rationality and the theory of rationality. Christian Scholars Review $15 / 4,372-387$.

FERRE, F 1980. Science, religion and experience, in Long, ET (ed), Experience, reason and God, 96-120. Washington: Catholic University of America Press.

GILL, JH 1981. On knowing God. Philadelphia: Westminister.

HEFNER, P 1985. Just how much can we intimate about reality? A response to Arthur Peacocke. Religion and Intellectual Life 2, 32-37.

KRIPKE, SA 1972. Naming and necessity, in Davidson \& Harman 1972: 253-355.

LAKOFF, G \& JOHNSON, M 1980. Metaphors we live by. Chicago: University of Chicago Press.

McMULLIN, E 1984. A case for scientific realism, in Leplin, J (ed), Scientific realism, 8-40. Berkeley: University of California Press.

McMULLIN, E 1985. Realism in theology and science: A response to Peacocke. Religion and Intellectual Life 2, 39-47.

McMULLIN, E 1986. Explanatory success and the truth of theory, in Rescher, N (ed), Scientific inquiry in philosophical perspective, 50-72. New York: Lanham.

McMULLIN, E [1987]. The shaping of scientific rationality: Construction and constraint. (Forthcoming.)

NEWTON-SMITH, WH 1981. The rationality of science. Boston: Routledge \& Kegan Paul.

O'HEAR, A 1984. Experience, explanation and faith: An introduction to the philosophy of religion. Boston: Routledge \& Kegan Paul.

PEACOCKE, A 1984. Intimations of reality: Critical realism in science and religion. Notre Dame: University of Notre Dame Press.

PROUDFOOT, W 1985. Religious experience. Berkeley: University of California Press.

PUTNAM, H 1975. Mind, language and reality. Philosophical Papers 2, 190-205.

ROTTSCHAEFER, WA 1985. Religious cognition as interpreted experience: An examination of Ian Barbour's comparison of the epistemic structures of science and religion. Zygon 20/3, 265-282. 
RUNZO, J \& IHARA, CK (eds) 1986. Religious experience and religious belief: Essays in the epistemology of religion. New York: University Press of America.

SCHOEN, EL 1985. Religious explanations: A model from the sciences. Durham: Duke University Press.

SOSKICE, JM 1985. Metaphor and religious language. Oxford: Clarendon.

SOSKICE, JM 1987. Theological realism, in Abraham, W] \& Holzer, SW (eds), The rationality of religious belief: Essays in honour of Basil Mitchell. Oxford: Clarendon.

TRIGG, R 1973. Reason and commitment. Cambridge: Cambridge University Press.

VAN HUYSSTEEN, W 1986. Teologie as kritiese geloofsverantwoording: Teorievorming in die sistematiese teologie. Pretoria: Raad vir Geesteswetenskaplike Navorsing.

VAN HUYSSTEEN, W 1987. The realism of the text. Pretoria: UNISA.

VAN HUYSSTEEN, W [1988]. Theology and the justification of faith. Grand Rapids: Eerdmans. (Forthcoming.) 